\title{
The Cruelty of American Apocalypse in Sam Shepard's Kicking a Dead Horse
}

\author{
Yasser Fouad Selim, PhD
}

\author{
Sohag University, Egypt \\ Email: yassfouad@gmail.com
}

\author{
Doi:10.5901/mjss.2016.v7n4p
}

\begin{abstract}
Sam Shepard's Kicking a Dead Horse (2007) has been censured by many critics for its repetition of Shepard's favorite theme of the American legendry West and the playwright's recurrent experimentation with Samuel Beckett's theatre of absurd dramaturgy. This study argues that the play garners its uniqueness from two aspects: The prophetic vision of America's decline, which links the play to the genre of apocalyptic writing, and the resurrection of Antonin Artaud's theatre of cruelty, which involves the audience emotionally and makes them positive viewers of the potential decline. This reading of the play emphasizes Shepard's thematic and theatrical innovation and his ability to dig deep into the American psyche to address critical concerns of the new millennium America.
\end{abstract}

Keywords: Sam Shepard, Kicking a Dead Horse, Theatre of Cruelty, Antonin Artaud, American Drama

\section{Introduction}

In his essay "Born Injured: The Theatre of Sam Shepard," American drama critic Christopher Bigsby (2002) notes that Shepard's theatre is concerned with "an engagement with America, with its myths, its failed utopianism, its spiritual attenuation, an engagement which hints at conservative radicalism as he challenges America with its rhetoric of innocence" (p. 8). The confrontation between America's realities and myths and the exploration of the American identity conflict are defining elements of Shepard's oeuvre. The family tragedies in Shepard's celebrated trilogy Curse of the Starving Class (1976), Buried Child (1979), and True West (1980) are emblems of a broader tragedy of a country failing to face its history while often celebrating its questionable innocence. In the later phase of Shepard's career, critics say very little when it comes to praise the playwrights' thematic and theatrical innovations. Kicking a Dead Horse (2007) has been censured by many critics for its recycling of Shepard's favorite theme of the American legendry West, the play's autobiographical repercussions, and the playwright's recurrent reworking with theatre of absurd aesthetics.

Kicking a Dead Horse, as I will argue in this paper, garners its uniqueness from two aspects: the prophetic vision of America's decline which links the play to the genre of apocalyptic writing, and the resurrection of Antonin Artaud's theatre of cruelty which connects the spectators emotionally to the American apocalypse. The paper is structured into three parts. The first part will survey the critical reception and the scholarly attention given to Kicking a Dead Horse. The second part will present a close reading of the play as an apocalyptic drama, and the third will investigate the theatrical aesthetics in the play in an attempt to demonstrate that Shepard instigates the audience's sense of fear over America's decline through his resurrection of Antonin Artaud's theatre of cruelty.

\section{Kicking a Dead Horse: Critical Reception}

A lonely aged man, Hobart Struther, is busy on stage digging a grave in a no-where desert to bury his dead horse which he is frequently kicking for leaving him alone in the remote prairie. Hobart indulges in various monologues to the audience and dialogues with his alter-ego about his past and America's history before he finally kicks the horse into the grave and sleeps alongside in the same hole. The death of the horse deprives Hobart from pursuing his trip to the American west to find what he calls "AUTHENTICITY" (Shepard 2007, p. 12).This is the core theme of Sam Shepard's play Kicking a Dead Horse. The play was first performed at the Peacock Theatre, Dublin, Ireland on 12 March 2007. Four days after the first performance of the play, Variety magazine reviewer Karen Fricker (2007) wrote that the play is "altogether a strange beast" as it carries "autobiographical material that seems a halfhearted attempt on Shepard's part to unload old creative baggage." The play's production on New York Public Theater in 2008 received similar criticism over its autobiographical nature. Toby Zinman (2008) of Philadelphia Inquirer argues that Shepard is "far more despairing and far less funny but 
just as autobiographical as his great play, 'True West' written 28 years ago." For Peter Santilli, the play is a "cerebral little drama" in which "the iconic writer treads on familiar ground-the wide-open frontiers of the American West." Malcom Johnson (2008) expresses his discontent with the play in a short expressive phrase: "Good ride, but a bit repetitive."

It is not only Shepard's failure to find a new thematic venue that disappoints critics of the play, but also the playwright's recurrent experimentation with Samuel Beckett's dramaturgy. Shepard's interest in Beckett's aesthetics started as early as his theatrical production Cowboys (1964) which was his first reflection upon his life in California and fascination with the cowboy mythology. The quasi-surrealist theatricalization of Kicking a Dead Horse, the play's sole character talking to himself and addressing the audience every now and then, and the staging of a horse and a pit that recreate the bare and unparticularized setting in Beckett's plays-all reflect a Beckettian absurdist ambiance. Stephen Rea, the Irish actor who played the character of Hobart Struther in the play, observes that both Shepard and Harold Pinter "claim the Beckettian existential space and re-locate it in rooms, ranches, prairies, badlands" (2007, p. x). Hobart, for many critics, seems to be coming out from a Beckettian drama and his meditation on his destiny in the vast prairie seems as absurd as Beckett's Vladimir and Estragon's dialogues in Waiting for Godot. Commenting on Hobart's comic wrestling with his circumstances and the surreal climate in the play, Sarah Hemming (2008) expounds that Hobart "could be a distant relative of Beckett's characters. So too the metaphysical implications of the play." Charles Isherwood (2008) proclaims that the play is "a conscious homage to Beckett." Stephen Bottoms (2015) goes further when he concludes, "Kicking a Dead Horse is Shepard's most knowingly Beckettian play to date" (p. 97).

Shepard's play was also poorly received in academic and scholarly criticism. To the best of my knowledge, there are only four published articles on the play, which focus primarily on metaphorical interpretations of Hobart's journey to the old West and the aesthetic connections to Samuel Beckett. The first scholarly article is a book chapter written by Terrence Hartnett (2009) and titled "Cowboy Consensus Or How we Learned to Stop Worrying and Love the War on Terror: Sam Shepard's Kicking a Dead Horse". As the chapter's title suggests, Hartnett interprets the play in the light of America's post-9/11 war on terror and makes parallels between Hobart Struther as a cowboy and George W. Bush, Jr. as a president from Texas. Like Hobart, the author argues, Bush presents himself as a cowboy personae and tries to breath new life into the American frontiers' mythos of expansion to unify the nation, claim political power after the terroristic attacks, and justify the occupation of overseas countries. The second essay is "Kicking a Dead Horse Horse: Burials and Resurrections" written by Gabriella Varró (2010) who reads the play as a daramatization of the playwrights' self. Varró's contribution to the play's criticism is represented in her valid argument that Shepard resurrects three theatrical figures in the play: Arthur Miller, William Shakespeare, and Samuel Beckett. Varró finds parallels between Hobart's shattered aspirations and Miller's characters' pipe dreams. She also makes references to King Lear's fool and Hobart's divided self, as well as Hamlet's gravediggers and Hobart's clownish behaviours. Furthermore, she reads Hobart's absurd situation to be equivalent to the characters' lives in Beckett's plays. The third article "'Semtimental Claptrap': Lost Cowbosy, Dead Horses, and the Discarded in Sam Shepard's Kicking a Dead Horse" offers a differnt reading of the play. The article's author Blake Westerlund (2015) elaborates in his long essay how Shepard trashes the American myths and images of the old west in oder to celebrate the endurance and resilience of music, dance, and art. Westerlund (2015) wrote another short essay titled "Cowgirl of the Prairie: Sam Shepard's Kicking a Dead Horse and an Enigmetic Appartition" in which he gives comments on the development of Shepard's treatment of women characters in the play.

I am not trying in this study to negate the different interpretations of the play. My reading is an attempt to present a different view that emphasizes Shepard's thematic and dramaturgical innovation and his ability to dig deep into American psyche and address critical concerns of the new millenium America. I suggest that Shepard puts a finger on the ignored violence and exclusionism of America and faces the nation with the fatal consequences of its imperialist mentality. Kicking a Dead Horse is not a lamentaion of American utopia, it is rather an excavation of a dystopia that is more threatening than nostalgic. I concur with The Financial Times critic John Murray Brown (2007) who remarks that the play reminds the American government of the shame brought by occupying sovereign nations like Iraq. Brown writes: "It is tempting to see political impulses in this latest work too - a plea that the US administration might reach some point of self knowledge and recognise it is 'kicking a dead horse' in Iraq." I would add that the play surpasses the denouncement of the occupation of Iraq to the criticism of America's long imperial history and the potential of America's decline and demise. The play suggests that America's apocalypse is inevitable if America continues to ignore its authentic founding ideals and the pitfalls of its imperialist mentality.

\section{American Apocalypse and the Question of Authenticity}

Apocalypse is a theological concept that refers to the eschatology and the end of the world beliefs. The earliest religious reference to apocalypse dates back to the Old Testament's Book of Daniel which carries Daniels' visions on the future of 
Israel until the end of times. In Christianity, the New Testament's Book of Revelation, which is also known as the Apocalypse of John, carries the so-believed last apostle's prophetic visions on the future of humanity in the end times of the cosmos. Islam also has its own versions of the apocalypse pronounced in the Quran and the Hadiths (prophet's sayings) that talk about the annihilation of human life before final resurrection and judgment. Scriptures and verses on apocalypse could also be found in Buddhism, Hinduism, and many other religions and philosophies. These religious classics and beliefs share together the anticipated dystopia at the finality of human existence on earth and the following chaos and ruin inflicted upon life by the divine.

The idea of apocalypse started to gain secular popularity and interpretations during the second half of the twentieth century when the complete destruction of the world became imminent due to the world powers' competition on the production and possession of nuclear weapons. In his book Alternative Modernity: The Technical Turn in Philosophy and Social Theory, Andrew Feenberg (1995) traces the emergence of critical consciousness of dystopia and apocalypse to the World War II era when the technological and weaponry advances secularized the end of the world myth and made it a possibility. That was reflected in the various essays written by scientists who wanted to awaken the world to the dangers of the technological advances, and insight the public of the necessity of nuclear weapons disarmament and the likelihood of a massive nuclear world war that could put an end to human life (1995, pp. 41-42). In secular apocalypticism, modernity and dangerous advancement replace supernatural elements as causes of destruction and ultimate devastation. Fiction, novels, films, and theatre find in the apocalypse a fertile topic for commercialization. Threatening stories of a world in apocalypse destroyed by aliens, earthquakes, nuclear explosions, robots, and various technological and environmental crises are described and filmed in works like I am a Legend, Star Wars, Armageddon, Hunger Games, Land of the Dead, Solar Attack, and many others. Secular apocalyptic writings and films gain huge public appeal because, to use Lorenzo DiTommaso's reasoning: "It transcends nearly every boundary-religious, cultural, linguistic, political, social, or economic. ... Apocalypticism can be espoused by the young and the old, by sectarians and centrists, by conservatives and liberals, by communists and capitalists, and by the religious and the irreligious. In a very real sense, it has mass appeal" (2014, p. 476).

Apocalypticism is a central metaphor in Kicking a Dead Horse. The play sets a threatening prophecy of America's decline and traces the country's dystopia to the founding era. America's cultural paradox of the celebration of its pioneering spirit and the negligence of the racist past Shepard reflects upon in his earlier works culminates in a potential collapse in Kicking a Dead Horse. This apocalyptic prophecy is put forward from the very beginning of the play through symbols and motifs that represent an end-of-history wasteland and a lurking demise. The empty stage, the endless horizon, the dead horse, the tomb, and the religious hymns the play begins with suggest a ruined earth where humans have already vanished. The play's sole character, Hobart Struther, finds himself alone in the prairie with no signs of life: "Now what? Nothing-nowhere - here I am-miles from nowhere. Only one day into it and bottomed out. Emptybadlands-horizon to horizon. No road-no car-no tiny house-no friendly 7-leven. Nada" (p. 10). Within this world of "nothingness", Hobart is the legendary apocalyptic hero who embarks on a "holy mission" (p. 12) to find the lost authenticity that would save the nation and replace its moral emptiness. The word "authenticity" which is recurrently spoken by Hobart refers to the frontiers' genuine adventurous spirit which seems to be taken over by the bare and vacant wilderness. The conflict between the American chivalric history and the colonial enduring legacy recalibrates the classical apocalyptic conflict between good and evil.

The apocalypse in Shepard's play, although taking place in modern America, carries biblical glimpses and references. Like John's prophecies in the Book of Revelation which are more visionary than real, Hobart's world is fantastic and imaginary. The whole play looks more dreamlike than real. Hobart confuses the audience over his situation from the early beginning of the play when he muses whether what he is experiencing is a work of imagination or reality: "What wild and wooly part of imagination dropped me here?" (p. 11). He admits that his mind "can't sit sill-squirmingharking back-leaping forward. Usually always back now, though-rarely forward" (p. 26). The religious references resonate also in the song of Dr. Malcom John Rebennack's 'Just a Closer Walk with Thee' which is selected by Shepard to play as the audience take their seats in the theatre. The song is traditionally performed in funerals and alludes to the dead's desire to be guided by Jesus:

Just a closer walk with Thee,

Grant it, Jesus, is my plea,

Daily walking close to Thee,

Let it be, dear Lord, let it be. 
Guide me gently, safely o'er

To Thy kingdom's shore, to Thy shore. ("Just a Closer Walk with Thee")

The play, however, is not only about Hobart's fall off. To me, Hobart is a replica of America itself. He is the American Everyman who is meditating over his history and the failed myths of the nation before the final ruin. The national conflict in the play goes hand in hand with Hobart's struggle between his old heinous self and his present confessional personae. Finding "the real" is Hobart's last chance to redeem his sinful days of yesteryear, and America's last chance to redeem its cultural hypocrisy, colonial legacy, and lack of truthfulness. Hobart's appearance on stage as a man of all ages supports my contention. He is a modern businessman in his mid-sixties travelling to the West on a horse. Despite his urban look, he carries a long list of objects that belong to the American past and present: saddles, bridles, horse blankets, canned beans, a cowboy hat, a bedroll, pots, pans, a can opener, a dental floss, and binoculars.

On stage, Hobart speaks in two voices: one that represents his real self and another that represents his alter ego. The dialogues Hobart has with himself are very argumentative and time surpassing. Like John in the Book of Revelation who visits the unknown through visions of a Son of Man who guides him to the secrets of hidden life and the hereafter, Hobart navigates into the past and meditates on his future via an omniscient voice that helps him to weigh the true against the false. He recalls the "truer" self he used to be before being overwhelmed by his growing sense of capitalism and "ecstasy for power" (p. 16). Everything went wrong when he started to purchase the paintings of some strangers for twenty bucks and sell them out for hundreds of dollars that turned into millions and made him a famous artist. These art objects become the demons that perpetually remind him of his fake success and the rise of America's delusions of capitalism and colonialism. His journey into the prairie is his last attempt for redemption. It is this "constant hankering for actuality" (p.16) and restoration of the lost frontiers' authentic spirit that bring him back to reconnect with the prairie. In her book West of Everything: The Inner Life of Westerns, Jane Tompkins states that the American West has been always a symbol of freedom and authenticity in American history. She explains:

This West functions as a symbol of freedom, and of the opportunity for conquest. It seems to offer escape from the conditions of life in modern industrial society: from a mechanized existence, economic dead ends, social entanglements, unhappy personal relations, political injustice. The desire to change places also signals a powerful space, the creak of saddle leather and the sun beating down, the horses' energy and force-these things promise a translation of the self into something purer and more authentic, more intense, more real. (1992, p. 4)

Hobart's definition of actuality as "the sense of being inside my own skin" (p. 16) is replete with meanings. He has lost this sense when he was eluded by his greed and "thrill of the kill" (p. 16). Likewise, America has lost its sense of freedom and originality when it was eluded by the thrill of territory expansion. This moral dystopia started far in the past and was realized by the early explorers. Mr. Meriwether Lewis shot himself after exploring and opening huge expanses in the American west because "maybe he realized something. Maybe he foresaw something. Maybe he did saw exactly what we were going to do with it" (p. 24). What Lewis has foreseen was probably the mystification of the frontiers' spirit or what Hartnett reads as a simulation of the original real spirit which replaces authenticity $(2009, p$. 62). The American west becomes a false duplication of the original, yet ironically more celebrated and recognized than the authentic. Hobart recalls Crazy Horse, the Native American hero who fought against the American federal government and lost his life in defense of his land when he was only 30 years old. Ironically, Crazy Horse is not honored in America while Hobart is a big shot despite his illegal ways of making success. The American decline, represented in the horse death, Hobart's selfblame, and the early explorers' pathetic suicides are all results of a moral dystopia and a denunciation of authenticity for power, expansion, and imperialism. Tracking back America's moral and political dystopia, Hobart rambles:

We closed the frontier in 1890-something, didn't we? Didn't we already accomplish that? The Iron Horse-coast to coast. Blasted all the buffalo out of here. An ocean of bones from sea to Shining sea. Trails of tears. Chased the heathen red man down to Florida. Paid the niggers off in mules and rich black dirt. Whupped the Chinese and strung them up with their own damned ponytails. Decapitated the Mexicans. Erected steel walls to keep the riffraff out. Sucked these hills barren of gold. Ripped the topsoil as far as the eye cans see. Drained the aquifers. Dammed up all the rivers and flooded the valleys for recreational purposes! Run off all the pathetic small farmers and transformed agriculture into "Agribusiness"! Destroyed education. Turned our children into criminals. Demolished art! Invaded sovereign nations! What more can we possibly do? (p. 62)

In an interview with Fintan O'Toole (2015), Shepard acknowledges these political dimensions of the play and asserts his view that the American War on Terror after 9/11 was a continuation of an imperialist ideology that has legacy in the early racism against immigrants and native inhabitants. He elaborates: 
There is this strange deal - from Lewis and Clark [who first explored the American West] to Iraq. It's very weird that we're continually trying to devour territory. It was about territory and it still is about territory, and ownership, and imperialism and conquering - taking it and doing something with it that we consider to be more useful than what's being done with it now. And consequently creating havoc and devastation. It's frightening, absolutely frightening.

This merge of the personal and the political consolidates the central metaphor in the play: America's apocalypse. Hobart's decline, as an American Everyman, represents a demise of America. His coming of age and weakness replicate America's collapse and loss of power. Like his horse which was "big good-lookin' son of a buck" (p. 21) back in the past and which died because of swallowing down extra chunks of oats, America was envisioned as a place of perfection in the "planning stage" (p. 23) before turning into a place of "shame" (p. 25). In a very meaningful monologue, Hobart mourns himself growing senile and at the same time bewails the country growing weaker.

The little conundrum mounted slowly to a frantic state of crisis. I was running out of time. Birthdays flying by - I could see it coming. I sat down with the wife, face-to-face. Told her - look now, here it is; right here in front of me. I've turned the corner. I can feel it creaking in my bones, my teeth - the eyes are all cloudy in the morning now. It's coming to get me, I swear. May be ten good physical years left and that's it - tits up; roll over, Beethoven. Ten years left to still throw a leg over a horse, like I used to; still fish waist-deep in a western river; still sleep out in the open on flat ground under the starry canopy — like I used to. (p. 18)

Shepard's arid sorrow for America's loss of authentic foundations and his apocalyptic vision of the nation are expressed in the play through two provocative symbols: the cowboy hat and the apparition of a nameless young woman. It is very suggestive noting that the disaster of Hobart-America's demise starts with the loss of Hobart's cowboy hat. It is the last item that Hobart reluctantly tosses into the pit after he easily gets rid of the saddle, the bridle, and the spur. The hat seems to be carrying its own mystery. Once thrown away, the final destruction begins. "This could really be it now. To lose the hat. ... It's not a good sign. This could finally be it" (p. 40), Hobart muses. Westerlund reads Hobart's tossing of the hat in line with many other critics who analyze Shepard's plays as a reconciliation of an unstable identity. "Tossing the hat aside is no small thing," Westerlund argues, "it is an acceptance of the almighty horse-grave abyss and the ultimate act of renunciation for what Hobart believed to be real and perhaps even sacred"(2015, p.57). The discarding of the hat, however, is more an act of despair than a dismissal of a myth. It is a sign of the inevitable apocalypse and the end of Hobart's futile quest for "authenticity." The hat, a symbol of the real old west and the freedom and authenticity of the despoiled frontiers, does not uphold in a new amoral land. Losing all means to resurrect the old-days authenticity, Hobart succumbs to decline and repeats the early explorers' suicide stories. Ridding himself of the hat concurs with a moment of sunset on the stage and the tremendous boom of the horse slamming to the ground, which encapsulates demise.

The other thought provoking symbol in the play is the young woman who appears in a sheer slip and bare feet. The woman appears near the end of the drama wearing Hobart's hat which has already been tossed into the grave. She silently puts it back on Hobart's head when he is totally unaware of her existence. Shepard, notorious for his poor development of female characters in his plays, presents this ghostly woman acting opaquely on stage. In a short paper written for The Explicator, Westerlund reads the enigmatic apparition of the woman as Shepard's "experimentation of the tiredly conventional gender roles of traditional formulaic western" (2015, p. 267). In another article, the same critic explains that the appearance of the nameless woman clouds what looks real in the play. He adds: "Whether the nameless Young Woman is a specter of the prairie, a device of the absurd, or a mirage created from an overtaxed and tired mind (or perhaps all of the above), the dancer's poetic movements remind the audience of Hobart's situation" (2015, pp. 53-54). This interpretation of the woman by Westerlund begs further exploration. To me, the woman is an angelic figure created by a tired mind, similar to the angel who handed John the messages from the messiah in the Book of Revelation. She is a supernatural character who ushers a moment of apocalypse. What supports my view is Hobart's comment, just before the girl appears on stage, that the dying horse is waiting for some "guardian angel" (p. 42) before his burial. It seems that even Hobart himself is waiting for a guardian angel before he buries the authenticity and freedom of the old west symbolized by the hat. The apparition of the girl is timely with the sound of distant prairie wind and Hobart's singing of "Oh, didn't he ramble" which is known as a funeral song that accompanies the burial of the dead. Unaware of her existence, the girl puts the hat on Hobart's head who tosses it again, this time willingly, into the pit.

As the play concludes, everything starts to collapse. The hat is deep in the hole, the horse is finally in the grave, the sky gets darker, and the sound of the prairie wind and thunder get louder and scarier. Hobart himself could not stand against the angry wind and darkness, and jumps down into the "infernal darkness" (p. 57) of the pit. It is the discovery that his truer self cannot stand against the atrocities made in his name that defeats Hobart. The final scene of Hobart descending into the grave he himself has dug is very symbolic, especially with the fusion of his own history with the 
American. Like Hobart, America has dug its own grave and is finally into abyss.

\title{
4. Artaudian Cruelty and the Spectacle of Apocalypse
}

The apocalypse of America is presented in the play in a manner which is absurd, engaging, cruel, and shocking. Staging a lonely man in the prairie trying absurdly to bury his dead horse and the apparition of a ghostly figure that is left inexplicable make the play's indebtedness to Samuel Beckett's theatre unmistakable. However, as I will argue in this part of the study, Kicking a Dead Horse is more indebted to Antonin Artaud's surrealist theatre of cruelty. It is worth mentioning here that the theatre of the absurd itself draws on elements of a previous tradition of surrealism that puts emphasis on the imaginary, the subconscious, and the dreamlike, and makes them significantly equal to reality in articulating meaning of everyday life. Martin Esslin (1960) argues that in absurd theatre "it is often unclear whether the action is meant to represent a dream world of nightmares or real happenings" (p. 3).

The American apocalypse in Kicking a Dead Horse is experienced by both Hobart and the audience through the on-stage trancelike climate which blurs the lines between the real and the imaginary, and the conscious and the subconscious. In surrealism, the real and the imaginary are not contradictions. They are both essential to reach the absolute meaning of life as Andre Breton (1996) states in his Manifesto of Surrrealism: "I believe in the future resolution of these two states, dream and reality, which are seemingly so contradictory, into a kind of absolute reality, a surreality, if one may so speak"(p. 14). The very beginning of Shepard's play confuses the audience over the boundaries of reality and fantasy. In his stage directions, Shepard insists that as the audience enter the theatre, the stage should be "entirely covered with a sky-blue silk sheet concealing irregular mounds" and the upstage wall is entirely covered with "white muslin scrim" (p. 7). Once the audience are settled, the stage lights turn pale to suggest the vast prairie, and the sky blue silk sheet is drawn back to reveal the dark pit Hobart has dug. Within this surrealist setting, Shepard advises, "the dead horse should be as realistic as possible with no attempt to stylize or cartoon it in any way" (p. 8). This amalgamation of reality and fantasy hypnotizes the audience before sailing into Hobart's visions as well as their own subconscious to witness the cruelty of a potential apocalypse and to liberate their fears over America's demise. What increases this emotional involvement in the action is the religious song playing as the drama begins.

This liberation of fears and imagination is what Antonin Artaud calls for in his theatre of cruelty. In his book The Theatre and its Double, Artaud calls for "a theatre that wakes us up: nerves and heart" (1958, p. 84) and "acts upon us like spiritual therapeutics whose touch can never be forgotten" $(1958, p .85)$. Artaud explains that by cruelty he does not mean physical violence, but the theatricalization of human passions, love, crime, struggle, and madness in a manner that feels terrible to the human spirit. This cruelty leaves an everlasting scar on the viewers, and liberates their imagination and dreams. Artaud elaborates:

\begin{abstract}
We want to make out of the theatre a believable reality which gives the heart and the senses that kind of concrete bite which all true sensation requires. In the same way that our dreams have an effect upon us and reality has an effect upon our dreams, so we believe that the images of thought can be identified with a dream which will be efficacious to the degree that it can be projected with necessary violence. And the public will believe in the theatre's dreams on condition that it takes (sic) them for true dreams and not for a servile copy of reality, on condition that they allow the public to liberate within itself magical liberties of dreams which it can only recognize when they are imprinted with terror and cruelty.(1958, pp. 85-86)
\end{abstract}

One can safely argue that the dreamlike and cruelty aspects highlighted by Artaud are essential elements in apocalyptic literature, whether biblical or secular. Apocalypticism is visionary, terrifying to the spirit, and aims at souls' redemption and catharsis. It often happens in difficult times and social unrest as a response to human fears (John's revelations were written when he was a prisoner of Rome on the desert of Patmos, and secular apocalypticism came out of the fears over the spread of mass destruction weapons). It is worth noting that Kicking a Dead Horse was written in a post-9/11 climate when many prophetic writings warned against the decline of America due to its political interference in global wars and conflicts. Robert D. Kablan, writing for the Atlantic in 2007, warns against "America's elegant decline". In 2013, Carlos Lozada wrote the following in an article for the Washington Post: "If the American superpower stretched out on a psychiatrist's couch and revealed its private terrors and most closely guarded insecurities, these are the images it would recall from its nightmares - the ones that roused it in a panic, afraid that its power and self-image were slipping away." I am not certain if Lozada has watched Shepard's Kicking a Dead Horse when he wrote his article, but I am certain that both Lozada and Shepard share the same sense of insecurity over America's deterioration. Both confront their readers/audience with the abyss waiting for them in a land that has lost its way and its genuine ideals. The monstrosity and falseness of the modern world are taking over the originality and authenticity of the past while everybody 
is secured within his/her isolated safe world. Cruelty builds up slowly in the play and encroaches the cozy physical and psychological territory of the audience who are made to share the same nightmare and confront the same terrible sensibilities of Hobart. The various monologues Hobart directs to the audience transform the stage and the auditorium worlds into one. The extendable prairie in the play looks inclusive of the stage itself as Hobart looks into the horizon (the auditorium) through his binoculars. Hobart's metanarratives represented in his dialogues to the audience and his comments on his situation reinforce the emotional connection between Hobart and the audience and function dramatically to support the idea of "the wilderness is theatre" as astutely remarked by Stephen Bottoms:

The play's inherent meta-theatricality performs at least two key dramatic functions. First, Hobart's need to 'imagine' an audience for himself highlights again the binary structuring of consciousness in terms of self and other, identification and repudiation. . . . Second, the play's meta-theatricality also serves to prevent any sense of unification in the representational apparatus: we are both in the wilderness and in the theatre. $(2015$, p. 98)

Reporting on the play's original production on the Abbey Theatre, Dublin, which was directed by Shepard himself, Bottoms refers to the various techniques Shepard used to remind the audience of the artifice of the stage that include: "a deft choreography of sudden lighting shifts and abrupt sound effects, intricately paced with the rhythms of Hobart's 'routines'. Whenever he attempts, and fails, to move the dead horse, for example, the corpse falls back into place with the 'boom' of amplified kettle drum"(p. 98). Shepard does not physically put the audience in the center of the stage as Artaud suggests in his theatre of cruelty theory, yet he could reframe the actors/spectators boundaries through Hobarts's various talks which penetrate the spectators' world and transmit to them his fears, worries, and nightmares. In this sense, the play is more illusionary and participatory than mimetic and thus pertains to one of the main characteristics of surrealist drama and more specifically to Artaud's theatre of cruelty. In one of his talks to the audience, Hobart warns them that apocalypticism is devouring their idleness and peaceful alienation: "Sitting around, folded up on sofas, sipping tea and reading. The Week in Review - the world going up in smoke across the blue Atlantic. Internecine warfare. Remote. Pathetic stud. Truly. Impotent" (19). This methectic nature of the play makes the audience active participants in the action and positive viewers of the apocalypse.

The "intense and sudden shock" (1958, p. 86) that Artaud finds indispensable to understanding one's position in life is explored in Kicking a Dead Horse through Hobart's furious moments and the culmination of natural disaster that finally staggers America's myths and Hobart's quest for the "real thing." In cruelty theatre, language expands to include lighting, music, sounds, explosions, and thunder to stir the audience's fear and pain, and to create "a thorough involvement, a genuine enslavement of the attention" $(1958,92)$. In a moment of fury, Hobart rips the paintings of Fredrick Remingtons and Charlie Russells, two of the most celebrated painters who captured the beauty of the American Old West in their works, and hurls them out of his window to hang around lampposts and be crushed by taxis. Reminding him of how originality is lost, the paintings "become like demon, glaring down at me, nostrils flaring, Colts revolvers blazing away" (p. 21). I share Hartnette's view that Hobart "has identified with the narratives of paintings and internalized their history as his own" (p.63) and would add that the spectators share Hobart the same sense of shame and the same internalization of the paintings' history. The beauty and symbols of the past truer days are crushed under modernity and falsehood. Also, the futile attempts of Hobart to drag the horse into the deep hole and his violent and repetitive kicking create a sense of fear and panic that the dead American horse could be ripped to ribbons by coyotes and vultures. Intensifying this sense of horror, Hobart addresses the audience bluntly that they may share the same destiny of the horse and that their decline is inevitable:

Can't help but feel you're digging your own damn tomb, with the damp walls growing higher and higher all around you, every shovelful. The smell too - the deeper you go. The history of it. The dinosaur bones. Ancient, aching bones. The fossil fuels. All the shit that roll through your numb skull as you shovel, one scoop at a time. Tedious stuff. You'd be surprised, the way the mind can't sit still - squirming - harking back - leaping forward. Usually always back now, though - rarely forward. No future - no with a dead horse and no prospects but hoofing it out into the Lone. Prairie for days on end. (pp. 26-27)

The audience may fall to Hobart's hypnotic suggestions and succumb to a mindful state of discovering their own absurdity that progresses as the play moves on. The cruelty that builds up slowly in the beginning of the play escalates into a sever sense of tension and terror near the end. Hobart's ranting increases and his kicking of the horse turns more savage as the wind grows ominously louder, the thunder roars higher, and the sky becomes darker. The tent which was protecting him, like the audience cocooned in their comfortable seats, finally could not stand against the fierce wind. The fall of the horse into the grave is accompanied by a loud brass that could be heard all over the theatre and the blow up of 
dust which fills the whole stage and creates a visual image of the apocalypse. The final song intensifies this apocalyptic atmosphere and alludes to collapse:
Oh, didn't he ramble
Oh, didn't he ramble
Rambled all around
In and out of town.
Oh, didn't he ramble
Oh, didn't he ramble
He rambled till the butcher
Cut him down. (p. 67)

Through this metaphysical journey into the future, the spectators could have what Artaud terms as "a transcendent experience of life" (p. 122). They are not passive viewers, but active spectators of the actions on stage. The Artaudian shock tactics Shepard incorporates in the play confront the audience with the nihilistic situation of the country and the potential collapse that could swallow everybody if "authenticity" is eventually lost.

\section{Conclusion}

The narratives of Hobart Struther in Kicking a Dead Horse encompass multiple spaces: Hobart as a fictional character, Shepard as a playwright, America as a nation, and the spectators as active participants. The monologues are therapeutically effective in uniting these multiple spaces, attaching them emotionally, and providing a space for catharsis through confronting their fears and anxieties. For Artaud, theatre is all "catharsis and spectacle" (Lewis, 2007, p. 200). Theatre is healing in the sense of exorcising the neglected sensibilities and imposing confrontation of the subconscious and the potential. The American apocalypse as a potential is cruelly staged in the play to confront Hobart, Shepard, the audience, and America itself with the ignored realities that have been internalized and not acknowledged. The acknowledgement of America's cruel history and pragmatic present is quintessential to maintain the country's ideals and founding principles. Reading the play from this perspective emphasizes that Shepard's literary status as the conscience of America is not waning. He is still one of the most innovative and critical playwrights in America's theatre history

\section{References}

Artaud, Antonin (1958). The Theatre and its double. Trans. Mary Caroline Richards. New York: Grove Press.

Bigbsy, Christopher (2002). "Born Injured: The Theatre of Sam Shepard." In Matthew Roudané (Ed.), The Cambridge Companion to Sam Shepard (pp. 7-33). Cambridge: Cambridge University Press.

Bottoms, Stephen (2015). "The Garden in the Machine: Edward Albee, Sam Shepard and the American Absurd." In Carl Lavery and Clare Finburgh (Eds.), Rethinking the Theatre of the Absurd: Ecology, the Environment, and the Greening of the Modern Stage (pp. 77-104). London: Bloomsbury.

Breton, Andre (1969). Manefestoes of Surrealism. Trans. Richard Seaver and Helen R. Lane. Michigan: University of Michigan Press.

Brown, John Murray (2007, March17). "American Angst in a Desert Landscape." Financial Times. Retrieved from: http://www.ft.com/int//cms/s/0/bbe1419a-d420-11db-83d5-000b5df10621.html

DiTommaso, Lorenzo (2014). "Apocalypticism and Popular Culture." In John J. Collins (Ed.), The Oxford Handbook of Apocalyptic Literature. Oxford: Oxford University Press.

Esslin, Martin(1960). "The Theatre of the Absurd." Tulane Drama Review, 4 (4), 3-15.

Feenberg, Andrew (1995). Alternative Modernity: The Technical Turn in Philosophy and Social Theory. California: University of California Press.

Fricker, Karen (2007, March 16). "Review: 'Kicking a Dead Horse."'Variety. Retrieved from: http://variety. com/2007/legit/reviews/kickinga-dead-horse-2-1200509633/

Hartnett, Terrence (2009). "Cowboy Consensus Or How we Learned to Stop Worrying and Love the War on Terror: Sam Shepard's Kicking a Dead Horse." In Judith Roof (Ed.), Talking Drama (pp. 57-76). New Castle upon Tyne: Cambridge Scholars Publishing.

Hemming, Sarah (2008, September 11). "Kicking a Dead Horse, Almeida, London." Financial Times. Retrieved from: http://www.ft.com/intt/cms/s/0/accfd65a-8020-11dd-99a9-000077b07658.html

Isherwood, Charles (2008, July 15). "Horse Can't Head Into the Sunset in Sam Shepard's New West."New York 
Times.http://www.nytimes.com/2008/07/15/theater/reviews/15kick.html

Johnson, Malcom (2008, July 15). " Good Ride, But A Bit Repetitious."Hartford Courant. Retrieved from: http://articles.courant.com/2008-

07-15/features/horserev.art_1_horse-trailer-american-west-dead-horse

"Just a Closer Walk with Thee." Timeless Truth. Retrieved from: http://library.timelesstruths.org/music/Just_a_Closer_Walk_with_Thee/

Kaplan, Robert D (2007, November). "America's Elegenat Decline." The Atlantic. http://www.theatlantic.com/magazine/archive/2007/11/america-s-elegant-decline/306344/

Lewis, Pericles (2007). The Cambridge Introduction to Modernism. Cambridge: Cambridge University Press.

Lozada, Carlos (2013, November 7). "America, Always Rising and Falling: Review of 'The Myth of America's Decline' by Josef Joffe."The Washington Post. Retrieved from: https://www.washingtonpost.com/opinions/america-always-rising-and-falling-review-of-themyth-of-americas-decline-by-josef-joffe/2013/11/07/3b296cfe-3f2a-11e3-a624-41d661b0bb78_story.html

O'Toole, Fintan (2007, February 24). "A Nod from One Sam to Another." The Irish Times. Retrieved from: http://www.irishtimes.com/news/a-nod-from-one-sam-to-another-1.1197044

Rea, Stephen (2007). "Forward." In Sam Shepard, Kicking a Dead Horse (pp. ix-xii). New York: Vintage Books.

Santilli, Peter (2008, July 14). "Sam Shepard Treads Familiar Ground in 'Kicking a Dead Horse'."The HighBeam Research. Retrieved from: https://www.highbeam.com/doc/1A1-D91TTLI00.html

Shepard, Sam (2007). Kicking a Dead Horse. New York: Vintage Books.

Tompkins, Jane (1992). West of Everything : The Inner Life of Westerns. New York: Oxford University Press.

Varró, Gabriella (2010): . "Kicking a Dead Horse: Burials and Resurrections." British and American Studies 16, 45-54.

Westerlund, Blake (2015):. "'Sentimental Claptrap': Lost Cowboys, Dead Horses, and the Discarded in Sam Shepard's Play Kicking a Dead Horse." Pivot: A Journal of Interdisciplinary Studies \& Thought, 4 (1), 40-73.

-(2015):. "Cowgirl of the Prairie: Sam Shepard's KICKING A DEAD HORSE and an Enigmatic Apparition." The Explicator 73 (4), 267269.

Zinman, Toby (2008, July 15). "Shepard's 'Horse' has a Certain Sameness."Philly.com. Retrieved from: http://articles.philly.com/2008-0715/news/25246140_1_dead-horse-hobart-struther-shepard-themes 